\title{
Pengaruh Pelayanan Fiskus, Pengetahuan Perpajakan dan Kesadaran Wajib Pajak Terhadap Kepatuhan Wajib Pajak dengan Kondisi Keuangan dan Preferensi Resiko Wajib Pajak Sebagai Variabel Moderating (Study Empiris pada Wajib Pajak Orang Pribadi di Kota Pekanbaru)
}

\author{
1,2,3 Universitas Riau \\ rima.yuslina@gmail.com
}

Prima Yuslina1, Amries Rusli Tanjung2 ${ }^{2}$, Alfiati Silfi ${ }^{3}$

\begin{abstract}
This research aims to examine the effect of tax authorities, tax knowledge and taxpayer awareness on taxpayer compliance with financial conditions and taxpayer risk preferences as a moderating variable. The sample in this study is 100 individual taxpayers who conduct business activities and free work in Pekanbaru Distribution of questionnaires is done by proportional sampling method. The questionnaire distributed was 110 , but only 100 could be processed with a response rate of $90.9 \%$. The data analysis technique in this research uses the classic assumption test, and Moderated Regression Analysis (MRA) through SPSS 23. The results of the testing of the research hypothesis indicate that of the nine hypotheses in this study, there were only 2 hypotheses that were not proven, namely hypothesis 5 , moderated tax knowledge financial conditions have an effect on taxpayer compliance and hypothesis 7, namely tax service providers moderated wp risk preferences affect taxpayer compliance. Meanwhile, 5 more hypotheses have proved to be influential.
\end{abstract}

Keywords: Taxpayer Compliance, Tax Services, Taxpayer Awareness, Financial Conditions and Taxpayer Risk Preferences

Penelitian ini bertujuan untuk menguji pengaruh pelayanan fiskus, pengetahuan perpajakan dan kesadaran wajib pajakterhadap kepatuhan wajib pajak dengan kondisi keuangan dan preferensi resiko wajib pajak sebagai variabel moderating. Sampel dalam penelitian ini 100 wajib pajak orang pribadiyang melakukan kegiatan usaha dan pekerjaan bebas di Pekanbaru Pembagian kuesionerdilakukan dengan metode proportional sampling. Kuesioner yang didistrubisikan 110, namun yang dapat diolah hanya 100 dengan respon rate sebesar90,9\%. Teknik analisis data dalam penellitian ini menggunakan uji asumsi klasik,dan Moderated Regression Analysis (MRA) melalui SPSS 23. Hasil pengujian terhadap hipotesis penelitian menunjukkan bahwa dari sembilan hipotesis dalam penelitian ini, hanya ada 2 hipotesis yang tidak terbukti yaitu hipotesis 5 yaitu pengetahuan perpajakan dimoderasi kondisi keuangan berpengaruh terhadap kepatuhan wajib pajak dan hipotesis 7 yaitu pelayanan fiskus dimoderasi preferensi risiko wp berpengaruh terhadap kepatuhan wajib pajak. Sementara itu, 5 Hipotesis lagi terbukti berpengaruh.

Kata Kunci: Kepatuhan Wajib Pajak, Pelayanan Fiskus, Kesadaran Wajib Pajak, Kondisi Keuangan dan Preferensi Resiko Wajib Pajak 


\section{PENDAHULUAN}

Pajak merupakan sumber utama bagi Negara Indonesia untuk mendanai Anggaran Pendapatan dan Belanja Negara (APBN) Lebih dari $75 \%$ sumber pendapatan Negara dari Pajak, sisanya dari kepabeanan, dan cukai, penerimaan bukan pajak dan hibah, dengan kata lain pajak merupakan sumber penerimaan Negara Indonesia. (www.kemenkeu.go.id/apbn2016).

Dalam UU No. 11 Tahun 2016 disebutkan bahwa untuk memenuhi kebutuhan penerimaan pajak yang terus meningkat, diperlukan kesadaran dan kepatuhan masyarakat dengan mengoptimalkan semua potensi dan sumber daya yang ada. Sementara kesadaran dan kepatuhan perpajakan masyarakat masih rendah.Maka diperlukan upaya untuk meningkatkan penerimaan pajak, baik dari segi insentifikasi maupun ekstensifikasi pajak.Mengingat jumlah angka wajib pajak yang baru mencapai sekitar 27 juta maka peluang insentifikasi pajak dalam hal peningkatan angka wajib pajak masih terbuka lebar yang didukung oleh peningkatan jumlah penerimaan pajak.

Sistem pemungutan pajak yang digunakan di Indonesia adalah self assessment.Dalam sistem ini wajib pajak diberi wewenang untuk menghitung, menyetor, dan melaporkan besarnya pajak terutang sesuai dengan jangka waktuyang telah ditentukan dalam peraturan perundang-undangan. Salah satu wajib pajak yang diminta untuk menghitung, menyetor, dan melaporkan besarnya pajak terutang adalah wajib pajak orang pribadi.Orang pribadi sebagai subjek pajak pribadi yang menurut ketentuan peraturan perundang - undangan perpajakan ditentukan untuk melakukan kewajiban perpajakan termasuk pemungutan pajak atau pemotongan pajak, seharusnya dapat mengelola usaha individualnya dengan lebih baik dibandingkan usaha organisasi.Dengan struktur yang ada, orang pribadi dapat mengatur seluruh pengeluaran dalam kegiatan usahanya agar memperoleh keuntungan yang diinginkan termasuk dalam mengatur kewajiban perpajakannya.

Keuntungan self assestment system ini adalah Wajib Pajak diberi kepercayaanoleh aparat pajak untuk menghitung, membayar, dan melaporkan sendiri pajak yang terutang sesuai dengan ketentuan perpajakan yang berlaku.Sebagai konsekuensinya Direktorat Jenderal Pajak berkewajiban untuk melakukan salah satu pengawasan dan pembinaan terhadap Wajib Pajak tersebut melalui pemeriksaan pajak.Sedangkan kelemahan self assestment system yang memberikan kepercayaan pada Wajib Pajak untuk menghitung, membayar dan melaporkan sendiri pajak terutang, dalam praktiknya sulit berjalan sesuai dengan yang diharapkan atau sering disalahgunakan.Hal ini dapat dilihat dari banyaknya Wajib Pajak yang dengan sengaja tidak patuh, dikarenakan masih rendahnya kesadaran masyarakat sehingga membuat Wajib Pajak sulit melaksanakan kewajiban membayar pajak.Rendahnya kepatuhan Wajib Pajak ini dapat dilihat dari kecilnya jumlah masyarakat yang memiliki Nomor Pokok Wajib Pajak (NPWP) dan mereka yang melaporkan Surat Pemberitahuan (SPT) Tahunannya (Indra Kusumawati, 2005:102).

Kepatuhan perpajakan merupakan suatu keadaan bahwa Wajib Pajak mempunyai kesediaan untuk memenuhi kewajiban pajaknya sesuai aturan yang berlaku tanpa 
perlu diadakannya pemeriksaan, investigasi, peringatan, ataupun ancaman (Gunadi, 2005:4)

Tabel 1.1

Realisai Penerimaan pajak Kota Pekanbaru Tahun 2014 s/d 2016

\begin{tabular}{|c|c|c|c|}
\hline Sumber Penerimaan & $\mathbf{2 0 1 4}$ & $\mathbf{2 0 1 5}$ & $\mathbf{2 0 1 6}$ \\
\hline Penerimaan Perpajakan & $10.816 .916,84$ & $12.732 .311,00$ & $12.623 .764,00$ \\
\hline Pph Non Migas & $4.039 .877,10$ & $4.156 .229,00$ & $4.050 .784,00$ \\
\hline Pax dan PPn.BM Indirect & $2.393 .115,77$ & $2.925 .446,00$ & $2.463 .901,00$ \\
\hline Pajak Lainnya Other Tax & $61.582,90$ & $82.858,00$ & $76.102,00$ \\
\hline PBB & $4.322 .341,07$ & $5.567 .778,00$ & $6.032 .977,00$ \\
\hline
\end{tabular}

Sumber : Kanwil Direktorat Jenderal Pajak Riau dan Kepulauan Riau

Berdasarkan Tabel 1.1 dapat dilihat bahwa setiap tahunnya terjadi perubahan pada penerimaan pajak.Pada Tahun 2014 Rp 10.816.916,84, Tahun 2015 Rp 12.732.311,00dan Tahun 2016 12.623.764,00.

Tercapainya penerimaan pajak suatu Negara tergantung pada berhasil atau tidaknya sistem pemungutan pajak yang diberlakukan di suatu Negara.Adanya upaya pemberlakuan system self assessment system diharapkan kepatuhan wajib pajakakan semakin meningkat seiring dengan tercapainya rencana penerimaan pajak. Kepatuhan wajib pajak dalam membayar kewajiban perpajakannya merupakan hal penting dalam penarikan pajak tersebut. Penyebab kurangnya kemauan membayar pajak tersebut antara lain adalah asas perpajakan, yaitu bahwa hasil pungutan pajak tersebut tidak langsung dinikmati oleh para wajib pajak. Upaya pendidikan, penyuluhan dan sebagainya tidak banyak berarti dalam membangun kesadaran wajib pajak untuk melaksanakan kewajiban pajak, jika masyarakat tidak merasakan manfaat dari membayar pajak, seperti jalan raya yang halus, pusat kesehatan masyarakat, pembangunan sekolah negeri, irigasi yang baik, dan fasilitas public lainnya. Masyarakat sendiri dalam kenyataan nya tidak suka membayar pajak.Hal ini disebabkan masyarakat tidak pernah mengetahui wujud konkret imbalan dari uang yang dikeluarkan untuk membayar pajak.

Berdasarkan data yang dimiliki Direktorat Jenderal Pajak jumlah wajib pajak yang terdaftaradalah sebagai berikut :

Tabel 1.2

Kepatuhan Wajib Pajak

\begin{tabular}{|r|l|c|c|c|}
\hline $\mathbf{N}$ & \multicolumn{1}{|c|}{ URAIAN/TAHUN } & $\mathbf{2 0 1 4}$ & $\mathbf{2 0 1 5}$ & $\mathbf{2 0 1 6}$ \\
\hline $\mathbf{O}$ & \multicolumn{1}{|c|}{$\begin{array}{l}\text { Wajib Pajak Orang Pribadi } \\
\text { Terdaftar }\end{array}$} & 196.425 & 162.607 & 232.477 \\
\hline 2 & $\begin{array}{l}\text { Wajib Pajak Orang Pribadi } \\
\text { Terdaftar Wajib SPT }\end{array}$ & 128.686 & 137.934 & 141.878 \\
\hline 3 & $\begin{array}{l}\text { \% Kepatuhan Wajib Pajak Orang } \\
\text { Pribadi }\end{array}$ & $60,97 \%$ & $55,61 \%$ & $55,82 \%$ \\
\hline
\end{tabular}


Berdasarkan tabel 1.2 mengenai Kepatuhan wajib pajak yang dimuat dalam Kanwil Direktorat Jenderal Pajak Riau dan Kepulauan Riau Tahun 2014 -2016 memperlihatkan bahwa ada kesenjangan yang cukup jauh antara jumlah wajib pajak terdaftar dengan penyampaian surat pemberitahuan (SPT) Tahunan pajak penghasilan (PPh).

Berbagai cara telah dilakukan oleh pemerintah agar dapat meningkatkan kepatuhan wajib pajak yang masih rendah khususnya yang sedang terjadi di Kota Pekanbaru saat ini. Salah satunya dengan meningkatkan kualitas pelayanan perpajakan.Selain di tunjang dengan pelayanan perpajakan yang modern diperlukan pelayanan dari pegawai pajak yang jujur, professional dan bertanggung jawab meningkatkan kepatuhan wajib pajak.

Pelayanan perpajakan atau pelayanan fiskus adalah dapat didefinisikan sebagai pelayanan dalam bentuk jasa di bidang perpajakan oleh Direktorat Jendral Pajak melalui satuan kerja yang ada dibawahnya dalam rangka memenuhi ketentuan perpajakan yang telah ditetapkan dan dapat menjadi sumbangan terbesar penerimaan Negara.

Selain Pelayanan fiskus atau pelayanan dari petugas perpajakan diperlukan pengetahuan perpajakan dan kesadaran perpajakan guna meningkatkan kepatuhan wajib pajak. Pengetahuan perpajakan itu sendiri di definisikan sebagai kemampuan atau seorang wajib pajak dalam mengetahui peraturan perpajakan baik itu soal tarif pajak berdasarkan undang-undang yang akan mereka bayar maupun manfaat pajak yang akan berguna bagi kehidupan mereka. Dengan adanya pengetahuan perpajakan tersebut akan membantu kepatuhan wajib pajak dalam membayar pajak, sehingga tingkat kepatuhan akan meningkat. Pada umumnya seseorang yang memiliki pendidikan, akan sadar dan patuh terhadap hak dan kewajibannya, tanpa harus dipaksakan dan diancam oleh beberapa sanksi dan hukuman.

Meskipun jumlah wajib pajak dari tahun ke tahun semakin bertambahnamun terdapat kendala yang dapat menghambat upaya peningkatan tax ratio,kendala tersebut adalah kepatuhan wajib pajak (tax compliance).Solich Jamin(2001) secara langsung menyatakan bahwa perlu peningkatan kepatuhan pajakguna meningkatkan tax ratio. Berdasarkan penelitian Solich Jamin (2001) jugadiketahui bahwa tingkat kepatuhan wajib pajak badan (WP Badan) dan wajib pajakorang pribadi (WP OP) ternyata lebih tinggi tingkat kepatuhan wajib pajak badan.Hal ini dapat terjadi karena wajib pajak badan lebih cenderung menggunakan konsultanpajak bahkan mempekerjakan karyawan yang secara khusus mengurusi masalahpajak perusahaan, berbeda dengan wajib pajak orang pribadi yang cenderung mengurusi sendirimasalah pajaknya.

Dalam melakukan pembayaran pajak, wajib pajak juga harus memperhatikan kondisi keuangan yang dimilikinya. Apabila penghasilan yang diterima telah melebihi Penghasilan Kena Pajak (PKP), maka wajib pajak diharuskan untuk membayar pajak dan wajib untuk melaporkan pajak penghasilan yang diterima wajib pajak ke kantor pajak. Wajib pajak juga harus dihadapkan oleh risiko yang 
harus dipertimbangkan ketika wajib pajak akan melakukan kewajibannya dalam membayar pajak. Risiko yang sering dipertimbangkan wajib pajak antara lain risiko kesehatan, risiko keuangan, risiko sosial, risiko pekerjaan dan risiko keselamatan (Aryobimo, 2012).

Preferensi risiko merupakan salah satu karakteristik individu dimana akan mempengaruhi perilakunya (Sitkin dan Pablo, 1992). Dalam konseptualisasi preferensi risiko yang lengkap, terdapat tiga cakupan yang mungkin. Tiga cakupan preferensi risiko tersebut meliputi menghindari risiko, netral dalammenghadapi risiko, dan suka mencari risiko.Sejumlah penelitian mengungkapkan bahwa sikap wajib pajak dalam menghadapi risiko tidak dapat dianggap remeh dalam kaitannya dengan kepatuhan (Alm dan Torgler, 2006; Torgler, 2003).Torgler (2007) menyampaikan bahwa keputusan wajib pajak individu dapat dipengaruhi oleh sikap mereka terhadap risiko.

Oleh karena itu, diperlukan penelitian lebih lanjut mengenai pengaruh pelayanan fiskus, pengetahuan perpajakan dan kesadaran wajib pajak terhadap kepatuhan wajib pajak dengan kondisi keuangan wajib pajak dan preferensi resiko sebagai variabelmoderating.

Fokus penelitianini adalah mencoba menambahkan 2 (dua) variabel yang dianggap dapat mempengaruhi kepatuhan wajib pajak. Variabel yang ditambahkan tersebut adalah pengetahuan perpajakan dan kesadaran wajib pajak. Walaupun terdapat penambahan variabel, tetapi fokus pada penelitian hanya pada satu tujuan yaitu kepatuhan wajib pajak. Dari sinilah yang membedakan penelitian sekarang dengan penelitian sebelumnya yaitu pada penelitian James O. Alabede (2011) variabel independen yang digunakan hanya 1 (satu) yaitu kualitas pelayanan fiskus, dan 2 (dua) variabel moderating yaitu kondisi keuangan dan preferensi risiko wajib pajak, sedangkan di penelitian ini terdapat 3(tiga) variabel independen yaitu pelayanan fiskus, pengetahuan perpajakan dan kesadaran wajib pajak, dan 2 (dua) variabel moderating yaitu kondisi keuangan dan preferensi risiko wajib pajak. Alasan penambahan variabel karena minimnya tingkat kepatuhan dikarenakan banyak terdapat tambahan wajib pajak baru yang kebanyakan lulusan sekolah dan kuliah dan saat ini belum memiliki pekerjaan serta kurangnya pengetahuan dan kesadaran wajib pajak baru mengenai mekanisme penyampaian surat pemberitahuan(SPT), sehingga yang bersangkutan tidak menyampaikan surat pemberitahuan(SPT)pajak penghasilan( $\mathrm{PPh}$ ) tahunan dan juga diasumsikan sebagai variabel yang diduga dapat digunakan sebagai indikator keberhasilan kepatuhan wajib pajak.

Selain itu, penelitian sebelumnya menggunakan objek penelitian yang dilakukan di Nigeria sedangkan pada penelitian ini peneliti ingin menerapkan penelitian tersebut di Indonesia yang sama - sama merupakan negara berkembang.

Oleh karena itu, berdasarkan kondisi yang telah dipaparkan di atas, penelitian ini mengkaji tingkat kepatuhan WP OP di Kota Pekanbaru karena kepatuhan masyarakat Indonesia masih rendah terutama WP OP di Kota Pekanbaru. Maka penulis tertarik untuk melakukan penelitian dengan judul "Pengaruh Pelayanan Fiskus, Pengetahuan Perpajakan dan Kesadaran Wajib Pajak Terhadap Kepatuhan Wajib Pajak dengan Kondisi Keuangan dan Preferensi Resiko 


\section{Wajib Pajak Sebagai Variabel Moderating (Studi Empiris Pada Wajib Pajak Orang Pribadi diKota Pekanbaru)".}

Berdasarkan uraian dalam latar belakang masalah diatas, maka dapat dirumuskan masalah pokok dalam penelitian ini yaitu :

1. Apakah pelayanan fiskus berpengaruh terhadap kepatuhan WP OP di Kota Pekanbaru?

2. Apakah pengetahuan perpajakan berpengaruh terhadap kepatuhan WP OP di Kota Pekanbaru?

3. Apakah Kesadaran wajib pajak berpengaruh terhadap kepatuhan WP OP di Kota Pekanbaru?

4. Apakah kondisi keuangan wajib pajak dapat memoderasi hubungan antara pelayanan fiskus dengan kepatuhan WP OP di Kota Pekanbaru?

5. Apakah kondisi keuangan wajib pajak dapat memoderasi hubungan antara pengetahuan perpajakan dengan kepatuhan WP OP di Kota Pekanbaru?

6. Apakah kondisi keuangan wajib pajak dapat memoderasi hubungan antara kesadaran wajib pajak dengan kepatuhan WP OP di Kota Pekanbaru?

7. Apakah preferensi resiko wajib pajak dapat memoderasi hubungan antara pelayanan fiskus dengan kepatuhan WP OP di Kota Pekanbaru?

8. Apakah preferensi resiko wajib pajak dapat memoderasi hubungan antara pengetahuan perpajakan dengan kepatuhan WP OP di Kota Pekanbaru?

9. Apakah preferensi resiko wajib pajak dapat memoderasi hubungan antara kesadaran perpajakan dengan kepatuhan WP OP di Kota Pekanbaru?

\section{TELAAH PUSTAKA}

\section{Teori atribusi}

Pada dasarnya teori atribusi menyatakan bahwa bila individu - individu mengamati perilaku seseorang, mereka mencoba untuk menentukan apakah perilaku itu ditimbulkan karena pengaruh internal atau eksternal

\section{Teori pembelajaran sosial (Social learning theory)}

Teori pembelajaran sosial ini relevan untuk menjelaskan perilaku wajib pajak dalam memenuhi kewajibannya membayar pajak. Seseorang akan taat membayar pajak tepat pada waktunya, jika lewat pengamatan dan pengalaman langsungnya, hasil pungutan pajak itu telah memberikan kontribusi nyata pada pembangunan di wilayahnya.

\section{Kepatuhan wajib pajak}

Kepatuhan berarti tunduk atau patuh,taat serta melaksanakan ketentuan perpajakan. Jadi, wajib pajak yang patuh adalah wajib pajak yang taat dan memenuhi serta melaksanakan kewajiban perpajakan sesuai dengan ketentuan peraturan perundang-undangan perpajakan.

\section{Pelayanan fiskus}

Pelayanan fiskus dapat diartikan sebagai cara petugas pajak dalam membantu mengurus atau menyiapkan segala keperluan yang dibutuhkan seseorang (dalam hal ini adalah wajib pajak). 


\section{Pengetahuan perpajakan}

Pengetahuan perpajakan adalah kemampuan atau seorang wajib pajak dalam mengetahui peraturan perpajakan baik itu soal tarif pajak berdasarkan undangundang yang akan mereka bayar maupun manfaat pajak yang akan berguna bagi kehidupan mereka.

\section{Kesadaran wajib pajak}

Kesadaran perpajakan adalah keadaanmengetahui atau mengerti perihal pajak. Penilaian positif masyarakat wajib pajakterhadap pelaksanaan fungsi negara oleh pemerintah akan menggerakkanmasyarakat untuk mematuhi kewajibannya untuk membayar pajak

\section{Kondisikeuangan}

Kondisi keuangan wajib pajak adalah tingkat kepuasan wajib pajak terhadap kondisi keuangan wajib pajak itu sendiri dan keluarganya.

\section{Preferensi resiko wajib pajak}

Preferensi resiko adalah resiko atau peluang yang akan dipertimbangkan oleh wajib pajak yang menjadi prioritas utama diantara yang lainnya dari berbagai pilihan yang tersedia.

\section{Kerangka Pemikiran dan Perumusan Hipotesis}

Terdapat 9 (sembilan) hipotesis yang akan dijabarkan sebagai berikut:

$\mathrm{H}_{1}$ : Pelayanan perpajakan berpengaruh terhadap kepatuhan wajib pajak orang pribadi.

$\mathrm{H}_{2}$ : Pengetahuan perpajakan berpengaruh terhadap kepatuhan wajib pajak orang pribadi.

$\mathrm{H}_{3}$ : Kesadaran wajib pajak berpengaruh terhadap kepatuhan wajib pajak orang pribadi

$\mathrm{H}_{4}$ : Kondisi keuangan wajib pajak memoderasi hubungan antara pelayanan fiskus dengan kepatuhan wajib pajak orang pribadi

$\mathrm{H}_{5}$ : Kondisi keuangan wajib pajak memoderasi hubungan antara pengetahuan perpajakan dengan kepatuhan wajib pajak orang pribadi.

$\mathrm{H}_{6}$ : Kondisi keuangan wajib pajak memoderasi hubungan antara kesadaran wajib pajak dengan kepatuhan wajib pajak orang pribadi.

$\mathrm{H}_{7}$ : Preferensi resiko memoderasi hubungan antara pelayanan perpajakan dengan kepatuhan wajib pajak orang pribadi

$\mathrm{H}_{8}$ : Preferensi Resiko memoderasi hubungan antara pengetahuan perpajakan dengan kepatuhan wajib pajak orang pribadi.

$\mathrm{H}_{9}$ : Preferensi Resiko memoderasi hubungan antara kesadaran wajib pajak dengan kepatuhan wajib pajak orang pribadi. 


\section{METODE PENELITIAN}

\section{Populasi dan sampel}

Populasi dalam penelitian iniadalah wajib Pajak Orang Pribadi yang melakukan kegiatan usaha dan pekerjaan bebas di Pekanbaru (kantor pelayanan pajak (KPP) Pratama Pekanbaru Senapelan dan kantor pelayanan pajak (KPP) Pekanbaru Tampan). Pengambilan sampel dilakukan dengan metode proportional samplinguntuk setiap kantor pelayanan pajak (KPP) di kota Pekanbaru (di kota Pekanbaru terdapat 2kantor pelayanan pajak (KPP) yaitu kantor pelayanan pajak (KPP) Pratama Pekanbaru Senapelan dankantor pelayanan pajak (KPP) Pekanbaru Tampan., maka ditetapkan jumlah kuesioner yang disebarkan sebayak 110 kuesioner.

\section{Jenis dan sumber data}

Ada dua jenis data yang digunakan dalam penelitian ini, yaitu data primerdan data sekunder.Sumber data primer pada penelitian inidiperoleh langsung dari para wajib pajak orang pribadi yang melakukan kegiatan usaha dan pekerjaan bebas yang berada di kota Pekanbaru. Data ini berupakuesioner yang telah diisi oleh para wajib pajak orang pribadi yang menjadi responden terpilih dalampenelitian ini.

Sedangkan data sekunder diperlukan dalam penelitian ini sebagaipendukung penulisan.Sumber data ini diperoleh dari berbagai sumber informasiyang telah dipublikasikan maupun dari lembaga seperti kantor pelayanan pajak (KPP). Data sekunder dalampenelitian ini berupa jumlah wajib pajak orang pribadi efektif terdaftar dan wajib pajak orang pribadi yangmenyampaikan surat pemberitahuan (SPT) yang diperoleh dari kantor pelayanan pajak (KPP) di wilayah Pekanbaru.

\section{Definisi operasional dan pengukuran variabel penelitian}

Dalam penelitian ini terdapat tiga variabel yaitu variabel independen, variabel dependen dan variable moderating.Definisi operasional dari masing-masing variabel tersebut adalah sebagai berikut :

\section{Variabel independent}

Variabel independen merupakan suatu tipe varibel yang menjelaskan atau mempengaruhi variabel lain dalam suatu penelitian. Dalam penelitian ini variabel independen yang dipakai adalah Pelayanan fiskus, Pengetahuan perpajakan dan Kesadaran perpajakan.

\section{Pelayanan Fiskus}

Pelayanan fiskus dapat diartikan sebagai usaha yang dilakukan untuk melayani wajib pajak secara maksimal agar wajib pajak tidak mengalami kendala yang cukup berarti saat memenuhi kewajiban perpajakannya(Mutia,2014). Rahayu (2010: 28) menyatakan salah satu langkah penting yang harus dilakukan pemerintah sebagai wujud nyata kepedulian pada pentingnya kualitas pelayanan adalah memberikan pelayanan prima kepada wajib pajak dalam mengoptimalkan penerimaan Negara. Alternatif jawaban atas daftar pertanyaan tersebut menggunakan skala likert dengan 5 poin.

2. Pengetahuan Perpajakan 
Pengetahuan perpajakan adalah kemampuan atau seorang wajib pajak dalam mengetahui peraturan perpajakan baik itu soal tarif pajak berdasarkan undang-undang yang akan mereka bayar maupun manfaat pajak yang akan berguna bagi kehidupan mereka.Alternatif jawaban atas daftar pertanyaan tersebut menggunakan skala likert dengan 5 poin.

3. Kesadaran Wajib Pajak

Kesadaran perpajakan adalah suatu kondisi dimana seseorang mengetahui, mengakui, menghargai dan menaati ketentuan perpajakan yang berlaku serta memiliki kesanggupan dan keinginan untuk memenuhi kewajiban perpajakannya. Penilaian positif masyarakat wajib pajak terhadap pelaksanaan fungsi negara oleh pemerintah akan menggerakkan masyarakat untuk mematuhi kewajibannya untuk membayar pajak.Alternatif jawaban atas daftar pertanyaan tersebut menggunakan likert dengan 5 poin.

\section{Variabel dependen}

Variabel dependen (Variabel terikat) dalam penelitian ini adalah kepatuhan wajib pajak.Kepatuhan pajak (tax compliance) adalah wajib pajak yang taat dan memenuhi serta melaksanakan kewajiban perpajakan sesuai dengan ketentuan peraturan perundang-undangan perpajakan.

\section{Variabel moderating}

Variabel moderating adalah Variabel yang dapat memperkuat atau memperlemah hubungan langsung antara variabel independen dengan variabel dependen.Variabel moderating dalam penelitian ini adalah kondisi keuangan wajib pajak dan Preferensi Resiko Wajib Pajak.

1. Kondisi Keuangan Wajib Pajak

Kondisi keuangan wajb pajak adalah tingkat kepuasan wajib pajak terhadap kondisi keuangan wajib pajak itu sendiri dan keluarganya.Alternatif jawaban atas daftar pertanyaan tersebut menggunakan likert dengan 5 poin.

2. Preferensi Resiko Wajib Pajak

Variabel preferensi diukur dengan menggunakan preferensi umum wajib pajak dengan mengambil risiko keuangan, risiko kesehatan, risiko sosial, risiko pekerjaan dan risiko keselamatan.Alternatif jawaban atas daftar pertanyaan tersebut menggunakan likert dengan 5 poin.

\section{Perumusan model penelitian}

1. Moderated Regression Analysis Sturktur I

$\mathrm{Y}=\alpha+\beta 1 X 1+\beta 2 X 2+\beta 3 X 3+\varepsilon$

2. Moderated Regression Analysis Sturktur II

$\mathrm{Y}=\alpha+\beta 1 X 1+\beta 2 X 2+\beta 3 X 3+\beta 4 Z 1+\beta Z 2+\varepsilon$

3. Moderated Regression Analysis Sturktur III

$\mathrm{Y}=\alpha+\beta 1 X 1+\beta 2 X 2+\beta 3 X 3+\beta 6 X 1 Z 1+\beta 7 X 2 Z 1+\beta 8 X 3 Z 1+\beta 9 X 1 Z 2+$ $\beta 10 X 2 Z 2+\beta 11 X 3 Z 2+\varepsilon$ 


\section{HASIL PENELITIAN DAN PEMBAHASAN}

\section{Statistik deskriptif}

Statistik Deskriptif memberikan gambaran atau deskripsi suatu data yang dilihat dari nilai rata-rata (mean), standar deviasi, varian, maksimum, minimum, sum, range, kurtosis dan skewness (kemenengan distribusi). Untuk memberikan gambaran analis statistik deskriptif (Ghazali, 2013).

\section{Uji instrumen penelitian}

Kualitas data yang dihasilkan dari penggunaan instrumen penelitian dapat dievaluasi dengan uji validitas dan uji reliabilitas (Aryobimo, 2012). Pengujian tersebut bertujuan untuk mengetahui konsistensi dan akurasi data yang dikumpulkan. Prosedur pengujian data adalah sebagai berikut:

1. Uji validitas

Validitas adalah keadaan yang menggambarkan tingkat instrument yang bersangkutan mampu mengukur apa yang akan di ukur (Yulianty, 2015). Uji Validitas digunakan untuk mengukur sah atau tidaknya suatu kuesioner. Suatu kuesioner dikatakan valid atau sahih jika pertanyaan pada kuesioner mampu mengungkapkan sesuatu yang akan diukur oleh kuesioner tersebut. Setiap pertanyaan yang diajukan dalam variabel kepatuhan wajib Pajak, pelayanan fiskus, pengetahuan perpajakan, kesadaran wajib pajak, kondisi keuangan dan preferensi resiko wajib pajak memiliki $r$ hitung $>r$ tabel. Dengan demikian semua butir pertanyaan variabel kepatuhan wajib pajak, pelayanan fiskus, pengetahuan perpajakan, kesadaran wajib pajak, kondisi keuangan dan preferensi resiko wajib pajak adalah valid.

2. Uji reliabilitas

Reliabilitas merupakan alat untuk mengukur suatu kuesioner yang merupakan indikator dari variabel atau konstruk. Suatu kuesioner dikatakan reliabel jika jawaban seseorang terhadap pertanyaan adalah konsisten atau stabil dari waktu ke waktu. Pengujian ini dilakukan dengan menghitung koefisien cronbach"s alpha dari masing - masing instrumen dalam suatu variabel. Berdasarkan hasil pengujian reliabilitas data untuk seluruh variabelpenelitian yaitu Kepatuhan WP, Pelayanan Fiskus, Pengetahuan Perpajakan, Kesadaran Wajib Pajak, Kondisi Keuangan dan Preferensi Resiko Wajib Pajak, diperoleh hasil lebih besar dari 0,6 yang berarti bahwa data tersebut reliable.

\section{Uji asumsi klasik}

Uji Asumsi klasik terdiri dari Uji normalitas data, Uji Multikolinearitas, Uji Autokorelasi, Uji Heterokedastisitas.

1. Uji normalitas data

Uji normalitas bertujuan untuk menguji apakah dalam model regresi, variabel pengganggu atau residual memiliki distribusi normal.Seperti diketahui bahwa uji t dan F mengasumsikan bahwa nilai residual mengikuti distribusi normal. Berdasarkan hasil uji kolmogorov smirnov, seluruh variabel yang diteliti yaitu Kepatuhan WP, Pelayanan Fiskus, Pengetahuan 
Perpajakan, Kesadaran Wajib Pajak, Kondisi Keuangan dan Preferensi Resiko Wajib Pajak memiliki nilai signifikansi $>0,05$, artinya seluruh variabel yang diteliti telah berdistribusi normal.

2. Uji multikolinearitas

Uji multikoliniearitas bertujuan untuk menguji apakah model regresi ditemukan adanya korelasi antar variabel bebas (independen).Model regresi yang baik seharusnya tidak terjadi korelasi diantara variabel independen. Pengujian multikolinearitas dilakukan untuk menjelaskan kemungkinan terdapatnya hubungan antara variabel independen yang satu dengan variabel independen yang lain. Berdasarkan hasil uji multikolinieritas setiap variabel nilai tolerancenya $>0,1$ dan nilai VIF $<10$ maka dapat disimpulkan bahwa variabel independen tidak mengalami gangguan multikolinieritas.

3. Uji heterokedastisitas

Pengujian terhadap heteroskedastisitas dilakukan dengan mengamati gambar hasil uji Glejser.Dalam regresi mungkin ditemui gejala heteroskedastisitas. Bila tidak terdapat heteroskedastisitas, maka nilai signifikansi $>0,05$ demikian pula sebaliknya. Heteroskedastisitas terjadi jika data memiliki nilai signifikansi < 0,05.Dari hasil uji heteroskedastisitas, terlihat sebaran data masing-masing variabel memiliki nilai signfikansi > 0,05 maka dapat disimpulkan seluruh variabel terbebas dari gejala heteroskedastisitas.

\section{Hasil uji koefisien determinasi (adj. $\mathbf{R}^{2}$ )}

1. Hasil uji koefisien determinasi (adj. $R^{2}$ ) MRA I

Tingkat koefisien determinasi yang diperoleh adalah sebesar Adj. $\mathrm{R}^{2}=0,489$. Hal ini berarti kepatuhan WP di kota Pekanbaru dalam membayar pajak dipengaruhi oleh variabel pelayanan fiskus, pengetahuan perpajakan, kesadaran wajib pajak sebesar 48,9\%. Sementara sekitar 51,10\% dipengaruhi oleh variabel lain.

2. Hasil uji koefisien determinasi (adj. $R^{2}$ ) MRA II

Tingkat koefisien determinasi yang diperoleh adalah sebesar Adj. $\mathrm{R}^{2}=0,507$. Hal ini berarti kepatuhan WP di kota Pekanbaru dalam membayar pajak dipengaruhi oleh variabel pelayanan fiskus, pengetahuan perpajakan, kesadaran wajib pajak, kondisi keuangan dan preferensi resiko wajib pajak adalah sebesar 50,70\%. Sementara sekitar 49,30\% dipengaruhi oleh variabel lain.

3. Hasil uji koefisien determinasi (adj. $\mathrm{R}^{2}$ ) MRA III

Tingkat koefisien determinasi yang diperoleh adalah sebesar Adj. $\mathrm{R}^{2}=0,583$. Hal ini berarti kepatuhan WP di kota Pekanbaru dalam membayar pajak dipengaruhi oleh variabel pelayanan fiskus, pengetahuan perpajakan, kesadaran wajib pajak,dengan pemoderasi kondisi keuangan dan preferensi 
risiko wajib pajak adalah sebesar 58,3\%. Sementara sekitar 41,70\% dipengaruhi oleh variabel lain.

\section{Hasil pengujian hipotesis dan pembahasan}

\section{Pengaruh pelayanan fiskus terhadap kepatuhan wajib pajak}

Hasil pengolahan data menunjukkan bahwa thitung $>t_{\text {tabel }}$ yaitu 2,928 $>1,984$ dengan nilai signifikansi sebesar 0,004 yang lebih kecil dari $\alpha=0,05$. Dari hasil pengujian terlihat, maka keputusannya adalah Ho ditolak dan $\mathrm{H}_{1}$ diterima. Oleh karena itu dapat disimpulkan bahwa pelayanan fiskus memiliki pengaruh signifikan terhadap kepatuhan WP dalam membayar pajak. Sehingga hipotesis pertama ( $\left.\mathrm{H}_{1}\right)$ diterima.Diterimanya hipotesis ini disebabkan kepatuhan wajib pajak dalam membayar pajak berkaitan dengan pelayanan yang diberikan fiskus. Artinya pelayanan fiskus dapat meningkatkan kepatuhan wajib pajak dalam membayar pajak mereka. Kepatuhan wajib pajak dalam membayar pajak dipengaruhi oleh beberapa faktor salah satunya adalah kualitas pelayanan yang diberikan fiskus kepada wajib pajak (Devano dan Rahayu 2006:112).

\section{Pengaruh pengetahuan perpajakan terhadap kepatuhanwajib pajak}

Hasil pengolahan data menunjukkan bahwa $t_{\text {hitung }}>t_{\text {tabel }}$ yaitu 2,560 $>1,984$ dengan nilai signifikansi sebesar 0,012 yang lebih kecil dari $\alpha$ sebesar 0,05. Dari hasil pengujian terlihat, maka keputusannya adalah $\mathrm{H}_{2}$ diterima dan Ho ditolak. Oleh karena itu dapat disimpulkan bahwa pengetahuan perpajakan memiliki pengaruh signifikan terhadap kepatuhan WP dalam membayar pajak. Hal ini berarti semakin banyak pengetahuan tentang perpajakan yang dimiliki oleh wajib pajak, maka akan meningkatkan kepatuhan WP dalam membayarkan pajak. Sehingga hipotesis kedua $\left(\mathrm{H}_{2}\right)$ diterima. Pengetahuan perpajakan merupakan sesuatu hal yang membuat kita menjadi tahu apa tujuan dan manfaat membayar pajak, kemudian apa sanksi yang akan diterima jika tidak membayar pajak. Dengan memiliki pengetahuan tentang perpajakan, maka kepatuhan wajib pajak untuk membayar kewajiban pajak mereka juga akan mengalami peningkatan. Semakin tinggi pengetahuan seseorang tentang perpajakan maka semakin tinggi tingkat kepatuhannya dalam membayar pajak.

\section{Pengaruh kesadaran wajib pajak terhadap kepatuhan wajib pajak}

Hasil pengolahan data menunjukkan bahwa thitung $>t_{\text {tabel }}$ yaitu 4,777> 1,984 dengan nilai signifikansi sebesar 0,000 yang lebih kecil dari $\alpha=0,05$. Dari hasil pengujian terlihat, maka keputusannya adalah Ho ditolak dan $\mathrm{H}_{3}$ diterima. Oleh karena itu dapat disimpulkan bahwa kesadaran WP memiliki pengaruh signifikan terhadap kepatuhan WP dalam membayar pajak. Hal ini berarti kesadaran WP dalam membayar pajak akan meningkatkan kepatuhan WP dalam membayar pajak. Sehingga hipotesis ketiga $\left(\mathrm{H}_{3}\right)$ diterima. Kesadaran wajib pajak berkonsekuensi logis untuk para wajib pajak agar mereka rela memberikan konstribusi dana untuk pelaksanaan fungsi perpajakan. Tingkat kesadaran yang tinggi akan membuat orang lebih memiliki kemauan dalam membayar pajak. Kesadaran wajib pajak adalah suatu kondisi dimana wajib pajak mengetahui, memahami dan melaksanakan ketentuan perpajakan dengan benar dan sukarela. Semakin tinggi 
tingkat kesadaran wajib pajak maka pamahaman dan pelaksanaan kewajiban perpajakan semakin baik sehingga dapat meningkatkan kepatuhan (Muliari dan Setiawan, 2010).

\section{Pengaruh pelayanan fiskus dengan pemoderasi kondisi keuangan terhadap kepatuhanwajib pajak}

Hasil pengolahan data menunjukkan bahwa $t_{\text {hitung }}<t_{\text {tabel }}$ yaitu 2,449>1,984 dengan nilai signifikansi sebesar 0,001 yang lebih kecil dari $\alpha$ sebesar 0,05. Maka keputusannya adalah Ho ditolak dan $\mathrm{H}_{6}$ diterima. Oleh karena itu dapat disimpulkan bahwa pelayanan fiskus dengan moderasi kondisi keuangan memiliki pengaruh signifikan terhadap kepatuhan Wajib Pajak dalam membayar pajak. Hal ini berarti pelayanan fiskus yang baik, akan ada artinya jika kondisi keuangan wajib pajak memungkinkan dirinya untuk membayar pajak.Torgler (2003) mengungkapkan bahwa seseorang yang mengalami kesulitan keuangan akan merasa tertekan ketika mereka diharuskan membayar kewajibannya termasuk pajak. Bloomqist (2003) mengidentifikasi bahwa tekanan keuangan merupakan salah satu sumber tekanan bagi wajib pajak dan Bloomqist juga berpendapat bahwa wajib pajak orang pribadi yang mempunyai pendapatan yang terbatas mungkin akan menghindari pembayaran pajak jika kondisi keuangan wajib pajak tersebut buruk karena pengeluaran keluarganya lebih besar dari pendapatannya.

\section{Pengaruh pengetahuan perpajakan dengan pemoderasi kondisi keuangan terhadap kepatuhan wajib pajak}

Hasil pengolahan data menunjukkan bahwa thitung $<t_{\text {tabel }}$ yaitu $0,783<1,984$ dengan nilai signifikansi sebesar 0,436 yang lebih besar dari $\alpha$ sebesar 0,05. Maka keputusannya adalah Ho diterima dan $\mathrm{H}_{5}$ ditolak. Oleh karena itu dapat disimpulkan bahwa pengetahuan perpajakan dengan moderasi kondisi keuangantidak memiliki pengaruh signifikan terhadap kepatuhan Wajib Pajak dalam membayar pajak. Hal ini berarti pengetahuan perpajakan yang baik, tidak akan ada artinya jika kondisi keuangan wajib pajak tidak memungkinkan dirinya untuk membayar pajak. Penelitian ini sejalan dengan penelitian Alabede, dkk (2011) yang menyatakan bahwa kondisi keuangan tidak berpengaruh signifikan terhadap hubungan antara pengetahuan perpajakan dengan kepatuhan wajib pajak

\section{Pengaruh kesadaran wajib pajak dengan pemoderasi kondisi keuangan terhadap kepatuhan wajib pajak}

Hasil pengolahan data menunjukkan bahwa thitung $>$ tabel yaitu 2,074>1,984 dengan nilai signifikansi sebesar 0,006 yang lebih besar dari $\alpha$ sebesar 0,05. Maka keputusannya adalah Ho ditolak dan $\mathrm{H}_{8}$ diterima. Oleh karena itu dapat disimpulkan bahwa kesadaran wajib pajak dengan moderasi kondisi keuangan memiliki pengaruh signifikan terhadap kepatuhan Wajib Pajak dalam membayar pajak.Kondisi keuangan seseorang mungkin secara positif atau negatif mempengaruhi kemauannya untuk memenuhi ketentuan pajaknya terlepas dari hubungan antara kepatuhan wajib pajak tentang kesadaran perpajakannya. Jadi dengan kondisi keuangan seseorang mungkin secara positif atau negatif mempengaruhi kemauannya untuk sadar atau secara sadar membayar pajak atau patuh terhadap pajak. 


\section{Pengaruh pelayanan fiskus dengan pemoderasi preferensi resikowajib pajakterhadap kepatuhan wajib pajak}

Hasil pengolahan data menunjukkan bahwa $t_{\text {hitung }}<t_{\text {tabel }}$ yaitu $0,643<1,984$ dengan nilai signifikansi sebesar 0,522 yang lebih besar dari $\alpha$ sebesar 0,05. Maka keputusannya adalah Ho diterima dan Hoditolak. Oleh karena itu dapat disimpulkan bahwa pelayanan fiskus dengan moderasi moderasi preferensi resiko wajib pajak tidak memiliki pengaruh signifikan terhadap kepatuhan Wajib Pajak dalam membayar pajak. Hal ini berarti pelayanan fiskus yang baik dapat meningkatkan kepatuhan wajib pajak dalam memabayar kewajiban pajak mereka namun tidak akan ada artinya jika terdapat moderasi dari preferensi resiko wajib pajak.Dari uraian di atas dapat diambil kesimpulan bahwa variabel preferensi risiko secara langsungdapat berpengaruh positif terhadap kepatuhan wajib pajak dalam membayar pajak tetapi apabila variabel preferensi resiko sebagai variabel moderating maka preferensi risiko dapat memperkuat atau memperlemah hubungan antara variabel independen dengan variabel dependen. Dalam penelitian ini variabel preferensi resiko tidak dapat memperkuat atau memperlemah hubungan antara preferensi wajib pajak tentang kualitas pelayanan pajak dengan kepatuhan wajib pajak dalam membayar pajak.

\section{Pengaruh pengetahuan perpajakan dengan pemoderasi preferensi resiko wajib pajak terhadap kepatuhan wajib pajak}

Hasil pengolahan data menunjukkan bahwa thitung $>t_{\text {tabel }}$ yaitu 3,000 $>1,984$ dengan nilai signifikansi sebesar 0,004 yang lebih kecil dari $\alpha$ sebesar 0,05. Maka keputusannya adalah Ho ditolak dan $\mathrm{H}_{8}$ diterima. Oleh karena itu dapat disimpulkan bahwa pengetahuan perpajakan dengan moderasi preferensi resiko wajib pajak memiliki pengaruh signifikan terhadap kepatuhan Wajib Pajak dalam membayar pajak. Hal ini berarti pengetahuan perpajakan yang baik, didukung dengan preferensi resiko wajib pajak akan memungkinkan dirinya untuk patuh membayar pajak.Adiasa (2013) menyatakan bahwa preferensi resiko dalam penelitian ini dimaksudkan untuk memoderasi hubungan antara variabel pengetahuan perpajakan terhadap kepatuhan wajib pajak. Hubungan antara variabel pengetahuan perpajakan terhadap variabel kepatuhan wajib pajak dapat dikatakan sangat berpengaruh positif terhadap kepatuhan wajib pajak apabila dapat dimoderasi oleh tingkat preferensi yang tinggi pada wajib pajak dalam menghadapi risiko yang muncul. Yang dimaksud dari preferensi resiko yang tinggi adalah keadaan dimana seorang wajib pajak akan menghadapi risiko yang berkaitan dengan kemungkinan membayar pajak atau risiko-risiko lainnya. Semakin tinggi kecenderungan dalam menghadapi resiko seorang wajib pajak maka akan semakin berpengaruh positif terhadap kepatuhan wajib pajak. Jadi, tingkat preferensi risiko wajib pajak tinggi maka dapat dikatakan dapat memoderasi hubungan antara pengetahuan wajib pajak terhadap kepatuhan wajib pajak.

\section{Pengaruh kesadaran wajib pajak dengan pemoderasi preferensi resiko wajib pajak terhadap kepatuhan wajib pajak}

Hasil pengolahan data menunjukkan bahwa thitung $>$ ttabel yaitu 3,997 > 1,984 dengan nilai signifikansi sebesar 0,000 yang lebih kecil dari $\alpha$ sebesar 0,05. Maka 
keputusannya adalah Ho ditolak dan H9diterima. Oleh karena itu dapat disimpulkan bahwa kesadaran wajib pajak dengan moderasi preferensi resiko WP memiliki pengaruh signifikan terhadap kepatuhan Wajib Pajak dalam membayar pajak. Hal ini berarti semakin baik kesadaran wajib pajak yang didukung preferensi resiko WP wajib pajak akan memungkinkan dirinya untuk membayar pajak. Torgler (2007) menyampaikan bahwa keputusan wajib pajak individu dapat dipengaruhi oleh sikap mereka terhadap resiko. Hubungan antara variabel kesadaran wajib pajak terhadap variabel kepatuhan wajib pajak dapat dikatakan sangat berpengaruh positif terhadap kepatuhan wajib pajak apabila dapat dimoderasi oleh tingkat preferensi yang tinggi pada wajib pajak dalam menghadapi risiko yang muncul. Yang dimaksud dari preferensi risiko yang tinggi adalah keadaan dimana seorang wajib pajak akan menghadapi resiko yang berkaitan dengan kemungkinan membayar pajak atau resiko-resiko lainnya. Semakin tinggi kecenderungan dalam menghadapi resiko seorang wajib pajak maka akan semakin berpengaruh positif terhadap kepatuhan wajib pajak. Jadi, dengan preferensi risiko seseorang mungkin secara positif atau negatif mempengaruhi kemauan nya untuk sadar atau secara sadar membayar pajak atau patuh terhadap pajak.

\section{KESIMPULAN, IMPLIKASI, KETERBATASAN DAN SARAN}

\section{Kesimpulan}

1. Pelayanan fiskus memiliki pengaruh yang signifikan terhadap kepatuhan wajib pajak di kota Pekanbaru.

2. Pengetahuan fiskus memiliki pengaruh yang signifikan terhadap kepatuhan wajib pajak di kota Pekanbaru.

3. Kesadaran wajib pajak memiliki pengaruh yang signifikan terhadap kepatuhan wajib pajak di kota Pekanbaru.

4. Pelayanan fiskusyang dimoderasi kondisi keuangan memiliki pengaruh yang signifikan terhadap kepatuhan wajib pajak di kota Pekanbaru.

5. Pengetahuan perpajakan yang dimoderasi kondisi keuangan tidak memiliki pengaruh yang signifikan terhadap kepatuhan wajib pajak di kota Pekanbaru.

6. Kesadaran wajib pajak yang dimoderasi kondisi keuangan memiliki pengaruh yang signifikan terhadap kepatuhan wajib pajak di kota Pekanbaru.

7. Pelayanan fiskusyang dimoderasi preferensi resiko wajib pajak tidak memiliki pengaruh yang signifikan terhadap kepatuhan wajib pajak di kota Pekanbaru.

8. Pengetahuan perpajakan yang dimoderasi preferensi resiko wajib pajak memiliki pengaruh yang signifikan terhadap kepatuhan wajib pajak di kota Pekanbaru. 
9. Kesadaran wajib pajak yang dimoderasi preferensi resiko wajib pajak memiliki pengaruh yang signifikan terhadap kepatuhan wajib pajak di kota Pekanbaru.

\section{Implikasi penelitian}

1. Dengan meningkatnya pengetahuan perpajakan masyarakat melalui pendidikan perpajakan baik formil maupun non formal akan berdampak positif terhadap pemahaman dan kesadaran wajib pajak membayar pajak.

2. Sanksi perpajakan merupakan alat pencegahan (preventif) agar wajib pajak tidak melanggar norma perpajakan, karena itu peningkatan pemahaman masyarakat melalui peningkatan sosialisasi dan realisasi atas sanksi yang diberlakukan diharapkan akan dapat meningkatkan intensitas kepatuhan wajib pajak dalam menjalankan kewajibannya sebagai warga negara yang baik.

3. Fiskus diharapkan meningkatkan kompetensi dalam arti memiliki keahlian, pengetahuan dan pengalaman dalam meningkatkan mutu pelayanan publik untuk wajib pajak, agar kesadaran wajib pajak meningkat.

\section{Keterbatasan}

1. Kuisioner yang dipakai peneliti sebelumnya, sehingga kemungkinan terjadinya kekeliruan dalam pengukurannya karena belum tentu menggambarkan keadaan yang sama pada objek peneliti sebelumnya.

2. Adanya keterbatasan waktu sehingga responden meminta kuisionernya ditinggalkan yang berdampak pada peneliti tidak bisa mendampingi responden pada saat menjawab. Akibatnya jawaban yang diberikan belum tentu menggambarkan keadaan yang sebenarnya.

\section{Saran}

1. Bagi peneliti selanjutnya agar dapat melakukan pengujian dengan menambahkan variabel lain,seperti sarana dan prasarana, partisipasi, dukungan teknologi informasi dan lain sebagainya serta membuat kuisioner yang baru dan disesuaikan dengan kondisi daerah yang diteliti sehingga dapat menggambarkan yang sebenarnya.

2. Pihak Ditjen Pajak diharapkan meningkatkan pelayanan fiskus dengan meningkatkan kompetensi yaitu keahlian (skill), pengetahuan (knowledge), dan pengalaman (experience).

3. Pihak Fiskus hendaknyadapat melakukan sosialisasi untuk meningkatkan pengetahuan masyarakat tentang perpajakan agar pemahaman dan kesadaran Wajib pajak untuk membayar kewajiban mereka dapat meningkat. Dengan penyuluhan perpajakan secara intensif dan kontinyu akan meningkatkan kepatuhan wajib pajak dalam membayar pajak. 


\section{Referensi}

Alabede, J. O., Affrin, Z. Z., Idris, K, M. 2011. Tax Service Quality and Tax Compliance in Nigeria : Do Taxpayer's Financial Condition and Risk Preference Play Any Moderating Role. European Journal of Economics, Finance and Administrative Sciences, (35), 90 - 108.

Alabade, Affrin dan Idris. 2011. Public Governance Quality and Tax Compliance Behavior in Nigeria: The Moderating Role of Financial Condition and Risk Preference. European Journal of Economics, Finance and Administrative Sciences.

Alm, J. \& Torgler, B. 2006. Culture differences and Tax Morale in United States and Europe. Journal of Economic Psychology, 27, 224 - 246.

Adiasa, Nirawan. 2013. Pengaruh Pemahaman Peraturan Pajak Terhadap Kepatuhan Wajib Pajak Dengan Preferensi Risiko Sebagai Variabel Moderating. Skrpsi Sarjana. FE UNNES. Semarang

Aryobimo, Putut Tri. 2012. Pengaruh Persepsi Wajib Pajak Tentang Pelayanan Aparat Pajak Terhadap Kepatuhan Wajib Pajak dengan Kondisi Keuangan dan Preferensi Resiko Sebagai Variabel Moderating (Studi Empiris Terhadap Wajib Pajak Orang Pribadi Di Kota Semarang).Sripsi Sarjana. FEB UNDIP. Semarang.

Ardyanto, Arif Angga dan Nanik Sri Utaminingsih, 2014, Pengaruh Sanksi Pajak Dan Pelayanan Aparat Pajak Terhadap Kepatuhan Wajib Pajak Dengan Preferensi Risiko Sebagai Variabel Moderasi, Jurnal Akuntansi, Vol. 3 No.2, Fakultas Ekonomi Universitas Negeri Semarang.

Bloomquist, K. M. (2003). Income inequality and tax evasion: A sysnthesis. Tax Notes International , 31(4),347-367

Caro and Garcia. 2007. Measuring Perceive Service Quality in Urgent Transport Service. Journal of Retailing and Costumer Servic. The Journal of Marketing. Vol. 49

Devano dan Rahayu, 2006."Perpajakan: Konsep, Teori, dan Isu". Kencana. Jakarta.

https://www.cnnindonesia.com/ekonomi/20170613131111-78-221378/googleakhirnya-sepakat-lunasi-tunggakan-pajak

Jamin, Solich. (2001) "Analisis Kepatuhan Wajib Pajak Sebelum dan Selama Krisis Ekonomi Pada KPP di Wilayah Jawa Tengah dan DI Yogyakarta”, Tesis Program Pasca Sarjana Magister Sains Akutansi Universitas Diponegoro.

Jatmiko, Agus Nugroho. (2006) "Pengaruh Sikap Wajib Pajak Pada Pelaksanaan Sanksi administrasi berupa denda, Pelayanan Fiskus dan Kesadaran Perpajakan Terhadap Kepatuhan Wajib Pajak (Studi Empiris Terhadap Wajib Pajak Orang Pribadi di Kota Semarang", Tesis Program Pasca Sarjana Magister Akutansi Universitas Diponegoro Semarang.

Lerche, Dietrich 1980, "Efficiency of Taxation in Indonesia," BIES, Vol. 16 No.1, p. $34-51$.

Monika, 2013, Pengaruh Kondisi Keuangan Wajib Pajak Terhadap Hubungan Antara Persepsi Wajib Pajak Tentang Kualitas Pelayanan Fiskus dengan Kepatuhan Wajib Pajak (Studi Empiris terhadap WPOP di Kota Bukit tinggi)

Mardiasmo .2016) .Perpajakan Edisi Terbaru . Yogyakarta : penerbit andi Yogyakarta 
Muliari, N.K., Setiawan P.E. (2010). Pengaruh Persepsi tentang Sanksi Perpajakan dan Kesadaran Wajib Pajak pada Kepatuhan Pelaporan Wajib Pajak Orang Pribadi di Kantor Pelayanan Pajak Pratama Denpasar Timur

Munari. 2005. Pengaruh Faktor Tax Payer terhadap Keberhasilan Penerimaan Pajak Penghasilan (Studi Kasus KPP Batu, Malang), Jurnal Eksekutif. Vol. 2, No. 2.

Rahayu, Siti Kurnia, Erly Suhayati. 2010. Perpajakan, Teori, dan Teknis Perhitungan. Yogyakarta: Graha Ilmu.

Robbins, S. 2008. Perilaku Organisasi, Jilid I dan II, alih Bahasa : Hadyana Pujaatmaja. Jakarta: Prenhallindo.

Sarjono, Haryadi dan Winda Julianita, 2011, SPSS vs Lisrel sebuah Pengantar Aplikasi Riset, Salemba Empat, Jakarta

Suandy Erly. (2014). Hukum Pajak ,Edisi 6.Yogyakarta : Penerbit Salemba Empat.

Sulud Kahono (2003), Pengaruh Sikap Wajib Pajak Terhadap Kepatuhan Wajib Pajak Dalam Pembayaran Pajak Bumi dan Bangunan : Studi Empiris di Wilayah KP PBB Semarang, Tesis Program Pasca Sarjana Magister Sains Akuntansi Universitas Diponegoro.

Suyatmin. (2004) "Pengaruh Sikap Wajib Pajak Terhadap Kepatuhan Wajib Pajak Dalam Pembayaran Pajak Bumi dan Bangunan: Studi Empiris di Wilayah KP PBB Surakarta", Tesis Program Pasca Sarjana Magister Sains Akutansi Universitas Diponegoro

Torgler, Benno. 2003. Theory And Empirical Analysis of Tax Compilance. Dissertation. Universitat Zurich

Utama T, Rd. Muhammad Faris. 2004. Pengaruh Kualitas Pelayanan Fiskus Terhadap Kepatuhan Wajib Pajak Dalam Membayar Pajak Kendaraan Bermotor (Studi Pada Kantor Samsat Puewakarta).Skripsi Program S1 Universitas Widyatama. Bandung.

Undang undang no 16 tahun 2009 tentang ketentuan umum dan tata cara perpajakan

www.pajak.go.id 